\title{
手術後再発肝細胞癌に対する transcatheter arterial embolization
}

\author{
山田 龍作* 中塚 春樹** 中村 健治** \\ 佐藤 守男* 小林 伸行** 高島 澄夫** \\ 貫野 徹*** 塩見 進***
}

要 旨: 手術後再発をきたした肝細胞癌の 2 例に transcatheter arterial embolization を行ない, 良好な成績を得た. 症例 1 は65藏, 男性で右葉切除 2 年後に発生した断端再発例である. 左肝動 脈内側枝の embolization を行ない, 血清 AFP 值の著減 $(28,200 \mathrm{ng} / \mathrm{m} l \rightarrow 6 \mathrm{ng} / \mathrm{m} l)$ をみた. 本例 は embolization 6 力月後の血管造影で腯瘍血管が全く消失したままで, 2 年後の現在, AFP 值 は正常範囲内で元気に生存中である. 症例 2 は72歳男性で左葉内側区域楔状切除 3 年後に, 肝両 葉に多発性の再発をきたした例である。左右肝動脈を 2 回に分けて，各々 embolization を行な った. 本例も 2 回の embolization により血清 AFP 值の著減 $(2,200 \mathrm{ng} / \mathrm{m} l \rightarrow 182 \mathrm{ng} / \mathrm{m} l)$ をみ, 1 年 4 力月後の現在む元気に生存中である.

手術後再発肝細胞癌症例には，従来有効な治療法がなかったが，embolization は患者に対する 侵襲の少ない，効果の著明な，副作用の少ない，優れた治療法と考えられた。

索引用語： arterial embolization 肝細胞癌 (手術後再発) 抗腫瘍潦法

はじめに

肝細胞癌は最す予後の悪い悪性腫瘍の一つであり，そ の治療法としては手術療法 ${ }^{1 \sim 4)}$, 化学療法 ${ }^{5 \sim 7}$, Transcatheter arterial embolization (以下 embolization) ${ }^{8-11}$ ) 等 があげられる．手術㙩法は治療法の第一選択とされる が, 肝細胞癌は早期発見が困難で, 診断確定時既に広範 囲飞進展している場合が多く，またしばしば高度の肝硬 变を合併するため，根治術の適応は狭い。また手術に成 功しても，その再発の頻度は高く2,3)，特にそのような 再発例に対しては治療法が活とんどないというのが現状 である.

我々は昭和52年から多数例の肝細胞癌に対し embolizationを行ない，手術に優るとも劣らない好成績を举 げ報告してきたが ${ }^{\mathrm{B}-11\}}$ ，今回は手術後再発肝細胞癌の 2 例化 embolization を行ない，良好な成績をおさめたの

\footnotetext{
* 和歌山紧立医科大学放射線科

**大阪市立大学放射線科

*** 同 第 3 内科
} <受付日57年 4 月 9 日 >

\section{で報告する・}

<症例 $1>65$ 歳, 男性

\section{症例}

昭和52年10月に右葉原発の肝細胞癌で肝右葉切除を受 けた. 切除標本の組織学的検討では Edmondson 开型肝 細胞癌であった。術前 $1,000 \mathrm{ng} / \mathrm{m} l$ と高值を示した血清 AFP 值は術後低下し, 正常範囲内となり，その後も低 值を維持していたが，昭和54年に入り，漸次上昇しは じ, 同年12月には $28,200 \mathrm{ng} / \mathrm{m} l$ Kまで上昇した．肝シ ソチグラムでも 残存肝左葉内側域に focal defect がみ られたため，肝細胞癌の手術後断端再発を疑い，血管造 影を施行した，腹腔動脈造影 (Fig. 1)で, 肝左葉は 良好飞再生肥大しているが, 左肝動脈内側枝領域に腫湯 血管の增生之睡瘍濃染がみられた。左肝動脈の他の領域 には尰湟血管は認められなかった。経動脈性門脈造影で は，門脈左枝は良好飞造影され，門脈本幹に腫湯浸潤像 は認められなかった. 以上の所見から，肝細胞癌手術後 断端再発之診断し, 再手術を考慮したが球存肝予備能が 低く，手術不能と考支られた。 そこで embolization の 


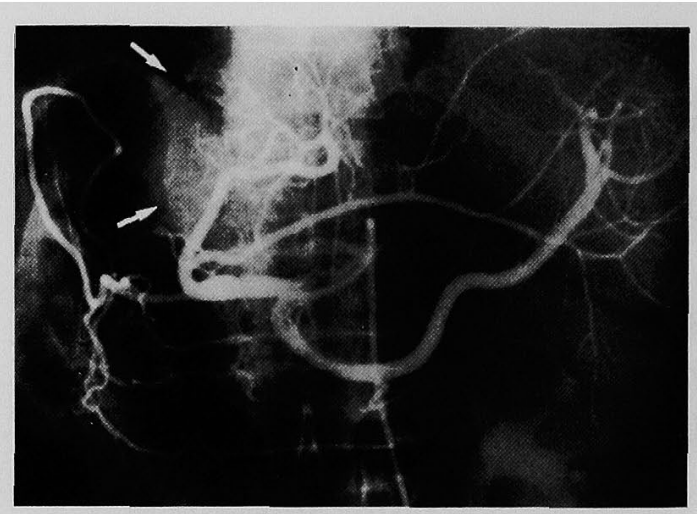

a

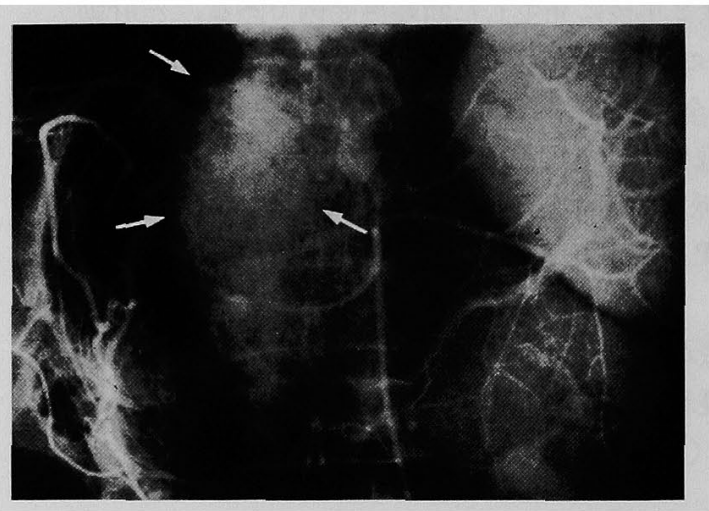

b

Fig. 1 Celiac arteriography, which was performed 2 years after right hepatectomy, reveals tumor vessels and tumor stain in the medial segment of the left liver lobe (arrow).

a, Arterial phase. b, Capillary phase.

適応と判断し，左肝動脈内側枝に MMC $10 \mathrm{mg}$ を渗み 込ませたぜラチンスポンジ細片を注入し， embolization を行なった (Fig. 2). embolization 後血掯 AFP 值は 衡前の $28,200 \mathrm{ng} / \mathrm{m} l$ から急速に下㦀し，85日目には $6 \mathrm{ng}$ / $\mathrm{m} l$ と正常値に戻った (Fig. 3). また, embolization 6 カ月後の腹垫動脈造影 (Fig. 4) では, embolization の なされた左肝動脈は閉塞し，腫湯血管は消失したままで あった。患者は embolization 後 2 年経過 Lた現在, AFP 值も正常範囲内で上昇傾向を示さず，通常の社会 生活を営なんでいる.

$<$ 症例 $2>72$ 歳, 男珄

阶左葉内側域に限寻した肝細胞癌で，昭和52年 7 月に 肝左葉内側楔状切除術を受けた。術後経過は良好であっ たが，昭和55年に入り漸次血清 AFP 值が上昇し，9月
23 巻10号（1982）

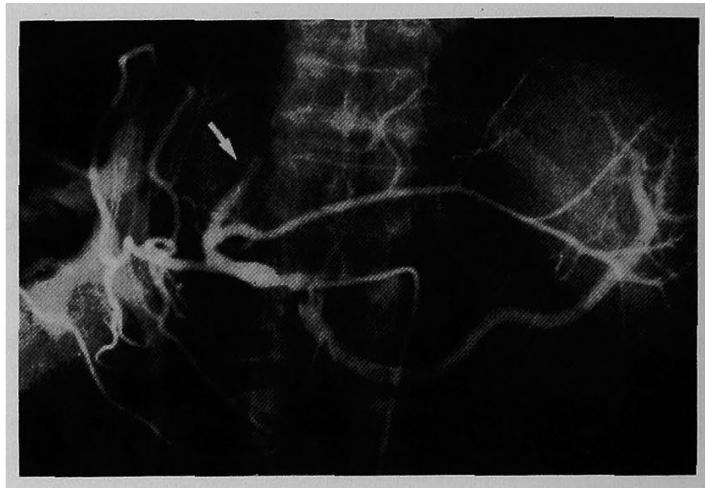

Fig. 2 Immediately after embolization, middle hepatic artery is completely occluded (arrow).

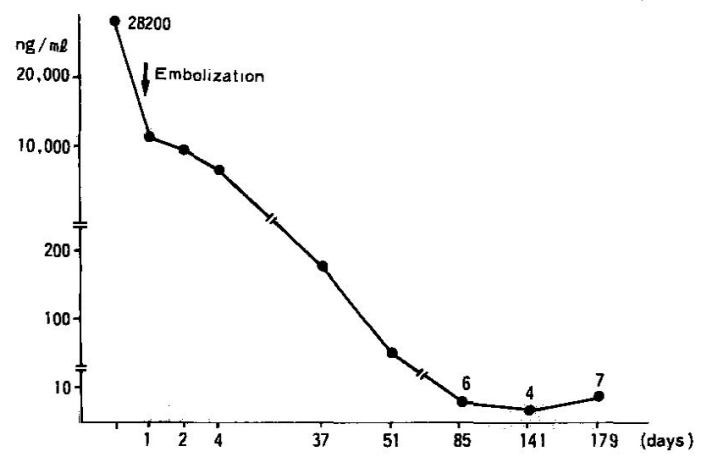

Fig. 3 Changes in serum $\alpha$-fetoprotein level in case 1 .

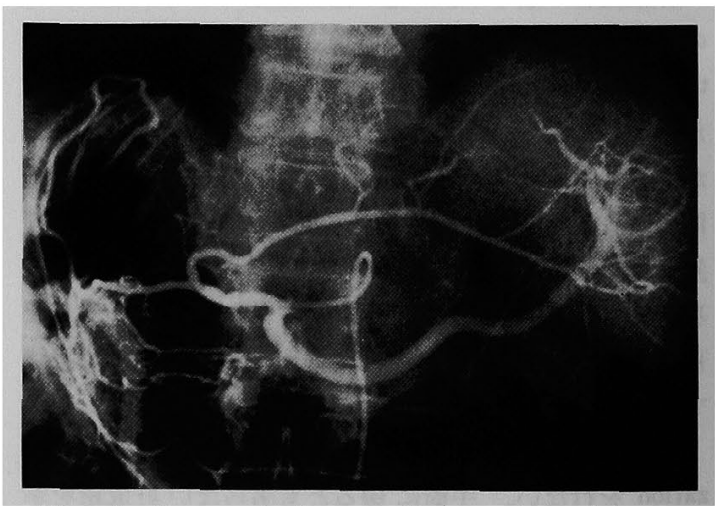

Fig. 4 Six months later, celiac arteriography, reveals occlusion of middle hepatic artery and no tumor vessels.

には2,200ng/m $l$ となり、肝細胞癌の手術後再発を寲い, 血管造影を坆行した．総肝動脈造影 (Fig. 5) で肺の両 葉に多数の 腫湯結節を認め, 肝細胞癌の再発と 診断乙 


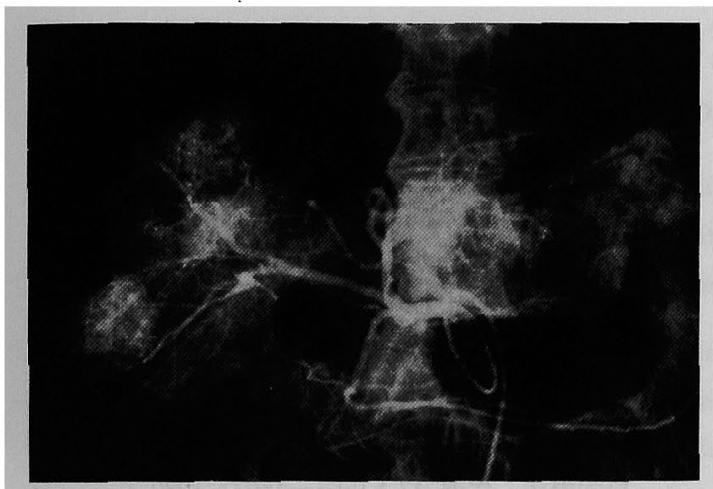

Fig. 5 Three years after wedge resection of the tumor in the medial segment, common hepatic arteriography reveals multiple tumor stains th the both liver lobes.

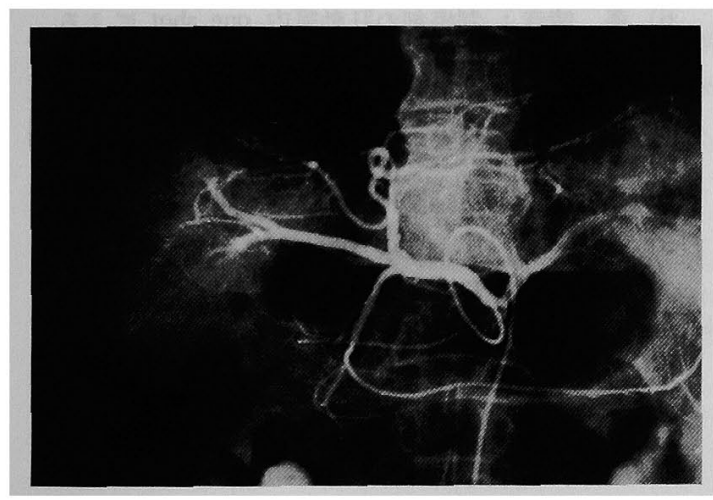

Fig. 6 Immediately after the first embolization, right hepatic artery is completely occluded.

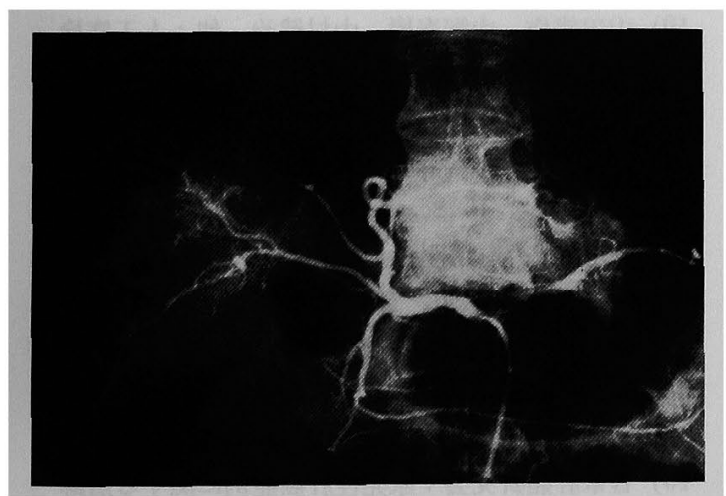

Fig. 7 Three weeks later, disappearance of tumor stains in the right liver lobe is noted.

た、をこで第 1 回目としては，まず石肝動脈に MMC $10 \mathrm{mg}$ を渗子込ませたゼラチンスポンジ細片を注入し， 右肝動脈のみの embolization を行なった (Fig. 6). 3

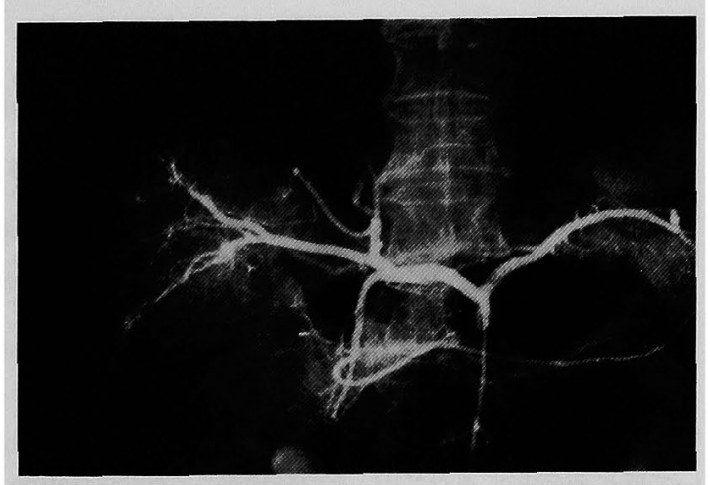

Fig. 8 Immediately after the second embolization, left hepatic artery is completely occluded.

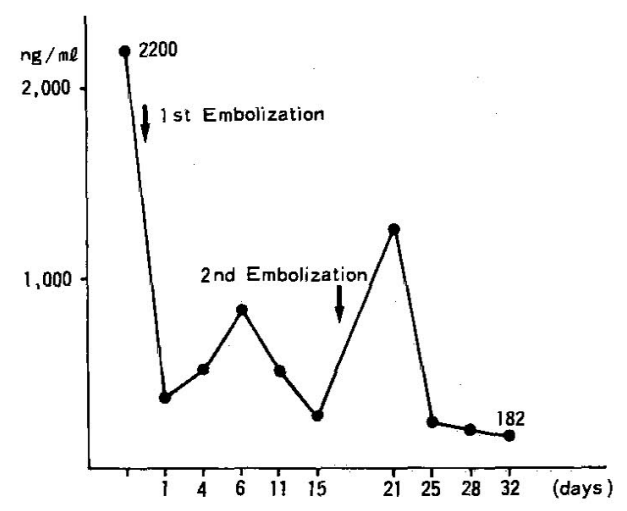

Fig. 9 Changes in serum $\alpha$-fetoprotein level in case 2.

週間後の腹腔動脈造影 (Fig.7) では, 右葉の腫瘍濃染 は選択的に消失し，左葉の腫煬濃染は残存していた。 そ こで2回目のとして左肝動脈の embolizationを行なっ た (Fig. 8). 血清 AFP 值仕 2 回の embolization によ り著減し，32日目には $182 \mathrm{ng} / \mathrm{m} l$ にまで低下した（Fig. 9). 患者は術後 I 年 4 力月の垷在も元気に外来通院中で ある.

\section{考案}

肝細胞癌は腫瘤の触知や隣接臓器への進展があって始 わて䛦断されることが多く，最も治療困難な尰瘍の一つ とされている，その治療法としては，従来手術療法 ${ }^{1 \sim 4}$, 化学療法 ${ }^{5 \sim 71}$ ，放射線潦法 ${ }^{(2)}$ などが行なかれてきた。 の中で最る優先するのは手術療法であるが, 最近の肝癌 研究会の報告ではその切除術は約 $9 \%$ と低く，また切 除できてもその一年生存率は $28 \%$ と不満足な成續であ る ${ }^{13)}$ 、これは，腫瘍が大きくて切除範囲が不充分となり 
断端再発をさたしたり，また手術時すで門脈系を介し て肝内に広く転移していて再発をきたすことが多いため と考号らる。

このよらな手術後再発肝細胞癌症例飞対しては, 再切 除は手術の根治性が低いことや，牫存肝予備能の面から 困難である. 化学療法も手術後すで施行されてきてい ることが多く，再発時には市まり效果を期待できず，む しろ強い副作用が前面に出ることが多い。

一方，我々は手術不能肝細胞癌火 embolization を行 ない良好な成縝を挙げ，その手技，効果，副作用等につ

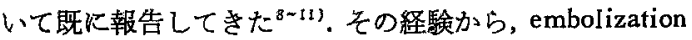
は患者に対する侵襲が小さく，抗腫湯效果が著明で，肝 機能におよぼす影響も軽度で一過性であり，全身的な副 作用もわずかであるので，このような手術後再発肝細胞 癌に対する治療法としても適当と考兑た。

我々が今回 embolization を行なった 2 例は 1 例が断 端再発，1例が両葉にまたがる肝内転移であったが，2 例ともに embolization の効果は良好で，血清 AFP 值

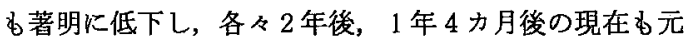
気に生存中である．また，副作用も軽微で，特に症例 1 は残存肝が左葉のみであったが術後，肝不全徵候も示さ ず, embolization 後10日で退院できた。一一方, 症例 2 は肝の両葉に多数の再発転移巣がみられたが，このよう な例でも時期を怙いて左右肝動脈を別々に embolization を行ならことにより，重篤な副作用もなく安全に治療す ることが可能であった。

一方，手術後再発肝細胞癌に対する embolization に 特ける問題点の 1 つは，手術によって腹腔動脈の血管走 向が著しく変化する可能性があることである.この場合 超選択的なカテーテル操作が困難となるが，我々が開発 した新しいガイドワイヤー（スーパーセレタターワイヤ 一) 14) 用いることにより克服できる，事実，我々の症 例 1 でる動脈の屈曲が強かったがカテーテル送入に成功 し，embolization を行ならことがでさた

以上，手術後再発肝細胞癌に対する embolizationは， 患者に対する侵襲が少なく，その効果は著明なるのがあ

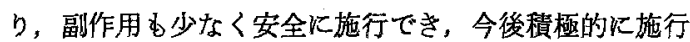
されるべき治療法と考えられた。

\section{まとめ}

手術後再発肝細胞癌の 2 例に transcatheter arterial embolization を施行し，良好な成績を得たので報告し た.

\section{文献}

1）本庄一夫，土屋凉一：盰癌の外科的治療. 日本 臨侏 $25: 2353-2359,1967$

2）菅原克彦, 河野信博, 白倉徹哉, 他 : 胉:癌切除 療法一々くにへパトーム切除後の病態生理を中 心とした検討一．外科 $37 ： 252-260 ， 1975$

3) 水本龍二，世古口努 : 肝癌の外科的治療一最近 10年の進歩と将来への展望一. 消化器外科 2 ： 1149-1156, 1979

4) 長谷川博, 山崎 晋, 幕内雅敏, 他 : 肝癌の外 科的療法。代謝 $17: 1555-1567 ， 1980$

5) 三浦 健, 石田正統：肝癌の化学療法一 $5 \mathrm{FU}$, MMC の肝動脈内注入療法の成績. 臨床と研究 $51: 368-377,1974$

6）澤 靖彦：制癌郕の肝動脈内 one shot Kよる 肝細胞癌の治療、肝臟 $20: 852$-859, 1979

7）鈴木 敞, 真辺忠夫, 戸部隆吉 : 血管カテーテ ルの治療への応用, 薬剂の注入一悪性腫瘍に対 乙て；肝癌一。踇外 $35: 335-342 ， 1980$

8) 山田龍作, 中塚春樹, 中村健治, 他 : 肝細胞癌 そ対する Transcatheter arterial embolization therapy一15例 の 経験一. 肝臓 $20: 595-603$, 1979

9）１. 田龍作, 中塚春樹, 中村健治, 他：肝細胞癌 K対する抗癌剤併用 Transcatheter arterial embolization therapy一CT 像からみた治療効果の 評価一. 日本医放会誌 $41: 15-23 ， 1981$

10）山田龍作, 中塚春樹, 中村健治, 他：人工塞栓 術の臨床応用, 肝癌への応用. 臨放 $26: 219$ 226, 1981

11）山田龍作, 中塚春樹, 中村健治, 他 : 肝細胞癌 に対する transcatheter arterial embolization therapy の有用性と肝機能に及ぼす影響. 日消 誌 $78: 214-221 ， 1981$

12）今永 - - , 黑柳弥寿雄, 金子昌生, 他 : 原発性 肝癌に対する Mitomycin C 之放射線との合併 療法. 臨放 $16: 374-380,1971$

13）日本肝癌研究会：原発性肝癌症例江関する追跡 調查一第 4 報一. 肝蔵 $20: 433-441,1979$

14）山田龍作, 工藤弘明, 奥山和夫, 他：われわれ が考案したスーパーセレクターワイヤーの各種 血管 カテーテル 術への応用. 脈管学 $21: 53$ 60,1981 


\title{
Transcatheter arterial embolization in recurrent hepatomas
}

\author{
Ryusaku Yamada*, Haruki Nakatsuka**, Kenji NAKAMURA**, Morio SATO*, \\ Nobuyuki KobaYASHI**, Sumio TAKASHIMA**, Toru KANNO*** \\ and Susumu SHIOMI***
}

Transcatheter arterial embolization was performed in two patients with recurrent hepatoma. Case 1, a 65-year-old man, who had been undergone right hepatectomy for hepatoma 2 years ago, had a relapse of tumor in the stump of the residual liver. Middle hepatic artery which fed the tumor was embolized. After embolization, serum $\alpha$-fetoprotein level markedly decreased from $28200 \mathrm{ng} / \mathrm{m} l$ to $5 \mathrm{ng} / \mathrm{m} l$ and follow-up angiography revealed complete disappearance of the tumor stain. Two years after embolization, this patient is still in healthy condition without re-elevation of $\alpha$-fetoprotein level. Case 2, a 72-year-old male, was undergone wedge resection of hepatoma in the left lobe. Three years after the operation, angiography revealed multiple tumor stains in the both lobes. Bilateral hepatic arteries were embolized respectively. Sixteen months later, this patient is still alive with relatively good condition. It is concluded, therefore, that transcatheter arterial embolization is an effective therapy for recurrent hepatoma.

\footnotetext{
* Department of Radiology, Wakayama Medical College (Wakayama)

** Department of Radiology, Osaka City University Medical School (Osaka)

*** IIIrd Department of Internal Medicine, Osaka City University Medical School (Osaka)
} 